\title{
Vegetation history and agriculture in the cover-sand area west of Breda (province of Noord-Brabant, The Netherlands)
}

\author{
Laura I. Kooistra
}

Received: 23 November 2006/Accepted: 20 March 2007/Published online: 19 June 2007

(C) Springer Verlag 2007

\begin{abstract}
Botanical investigation of archaeological sites situated in the northwest of the region bounded by the rivers Maas, Scheldt and Demer ('MSD region'), west of the city of Breda, has provided a great deal of evidence about the landscape and its use in the period between 2000 B.C. and A.D. 1500. From pollen analysis, it appears that this cover-sand area gradually lost its woodlands through human activity after the beginning of the Bronze Age (ca. 2000 B.c.). Patches of woodland did survive there, however, until the early Middle Ages. In contrast to the cover-sand area in the vicinity of 's-Hertogenbosch and Oss-Ussen in the northeast of the MSD region, the first large heathlands in the Breda area did not evolve until the early Middle Ages. In late prehistory, land use in this area was not much different from that in the microregion of 's-Hertogenbosch and Oss-Ussen. In the Bronze Age, Hordeum vulgare ssp. vulgare (hulled six-row barley) and Triticum dicoccon (emmer wheat) were grown. During the Iron Age, Panicum miliaceum (common millet) and $T$. spelta (spelt wheat) were introduced, but these crops disappeared during the Roman period. The Roman period is remarkable because of the lack of any Mediterranean culinary herbs or exotic fruits. Only pollen of Juglans regia (walnut), found around the transition from the Roman period to the early Middle Ages, indicates the introduction of an exotic tree into the region. From the early Middle Ages onwards, Secale cereale (rye) was the most important cereal, which was grown as a winter crop. In the course of the Middle Ages, arable
\end{abstract}

L. I. Kooistra $(\bowtie)$

Biax Consult, Hogendijk 134, 1506 AL Zaandam, The Netherlands

e-mail: kooistra@biax.nl weeds of the Sclerantho annui-Arnoseridetum plant community appeared, which is associated with the continuous growing of rye.

Keywords Vegetation history · Farming · Cover-sand area - Maas · Scheldt and Demer regions - Palynology · Botanical macroremains

\section{Introduction}

In the 1980s and 1990s Corrie Bakels began research in the northeastern part of the so-called Maas, Scheldt and Demer region (MSD region), especially near Oss and 's-Hertogenbosch (Fig. 1). A brief summary of the results of all these investigations shows the following changes in landscape and farming from the Neolithic (in the Netherlands: 5300-2000 B.c.) onwards. During the Neolithic, people lived in closed woodland (Bakels 2002; Van Beurden 2002a). Pollen analyses show that Quercus (oak), Tilia (lime), Fraxinus excelsior (ash), Ulmus (elm) and Betula (birch) were the main trees in the deciduous woodland. The sometimes fairly high counts of pollen of Corylus avellana and spores of Pteridium aquilinum point to openings in the forest. Pollen of crops like Hordeum/ Triticum (barley/wheat) and Linum usitatissimum (flax) suggests that these open patches were clearings made by human activity (Bakels 2002). The life of the Bronze Age farmers (2000-800 B.c.) at Oss was reconstructed by Schinkel (1998). The farmers lived in a large territory in which every generation built a farmhouse at a new location within the territory. Schinkel called this the 'unsettled settlement' system. At Oss the botanical macroremains from this period included just a single carbonized grain of Hordeum vulgare (six-row barley) 


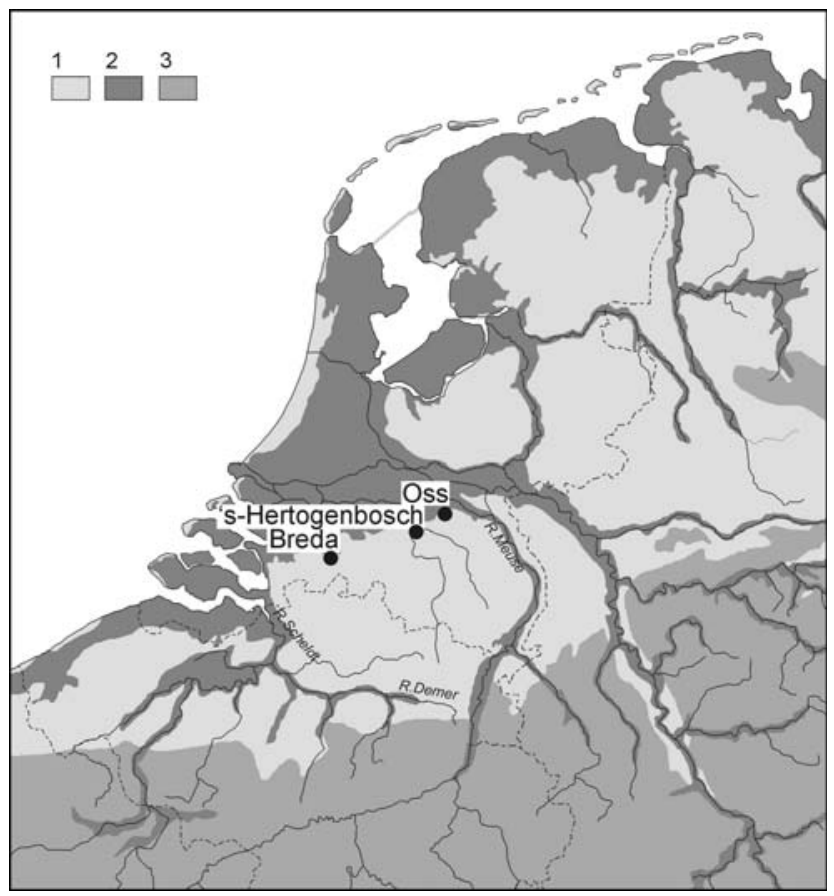

Fig. 1 Location map of the research area in the Maas, Scheldt and Demer region (MSD region). 1 Pleistocene sandy soils and dunes; 2 Holocene soils; 3 elevation $>100 \mathrm{~m}$

(Bakels 1980), but slightly further southeast, the settlement sites at Hooidonksche Akkers (Bakels and Van der Ham 1980) and Geldrop (De Hingh 2000) contained more macroremains providing evidence of food production and consumption. Hordeum vulgare ssp. vulgare (hulled six-row barley), Triticum dicoccon (emmer wheat), T. aestivum (bread wheat) and Panicum miliaceum (millet) were the main crops. Moreover, there is evidence for the gathering of Quercus (acorns). Because of the system of unsettled settlements, the landscape was a patchwork of fields, regenerating natural vegetation and virgin woodland. Because of the low fertility of the cover-sand soils in the northeastern MSD region, much abandoned farmland degraded into heath rather than woodland in the course of the Bronze Age (Van Beurden 2002a; De Kort 2002). The first signs of this change are visible as early as the late Neolithic (2800-2000 в.c., Bakels 2002). During the Iron Age (250-12 в.с.) the same crops were grown as in the Bronze Age, supplemented by $T$. spelta (spelt wheat), Camelina sativa (gold-of-pleasure), Papaver somniferum (poppy), Brassica rapa (turnip) and Vicia faba (Celtic bean); (Bakels 1998). The Iron Age farmers lived in an open landscape, which had few trees. From the late Iron Age onwards the settlements became permanent. The Roman period (12 B.C.-A.D. 450) brought the first grains of Secale cereale (rye). Influences in the diet from central and Mediterranean Europe are visible in the introduction of Juglans regia (walnut) and several Mediterranean kitchen herbs (Bakels et al. 1997; Van Beurden 2002b). Pollen analyses by Van Beurden (2002a) show a degree of regrowth of woodland at the beginning of the early Middle Ages (from A.D. 450) followed by further woodland loss from the eighth century onwards. Because of the poor soils (in part still under heather) the only cereals grown were Avena sativa (oat), barley and rye (Van Beurden 2002b). Kitchen herbs, domesticated fruits and nuts formed part of people's diet. The agriculture of the late Middle Ages (A.D. 1050-1500) in the vicinity of 's-Hertogenbosch was investigated by Van Haaster (2003). He found evidence of permanent $S$. cereale (rye) cultivation and an intensifying production of Fagopyrum esculentum (buckwheat) from the last quarter of the 13th century onwards. On the nutrient-poor, sandy soils flax and (Celtic) beans were also grown, as demonstrated by Van Beurden (2000a).

Breda-West lies in the extreme northwest of the MSD region (Fig. 1). Until recently, very little was known about the occupation history of this area in prehistoric and early historical times. This changed when, in the mid-1990s, plans were made for building an industrial estate to the west of the city of Breda and for a high-speed railway line connecting Paris and Amsterdam that was to pass through the same area. These developments posed a threat to any archaeological remains present in the soil. Therefore the local authority of Breda and the Directorate of Public Works and Water Management of the Netherlands each commissioned large-scale archaeological research projects, in anticipation of the ratification of the European Convention of Valletta by the Dutch parliament. The archaeological investigation on the industrial estate was carried out by the municipality of Breda (Koot and Berkvens 2004). The archaeological investigation of the projected railway route was carried out by Archeologisch Diensten Centrum, commissioned by Projectgroep Archeologie HSL-Zuid/A16 (Kranendonk et al. 2006). These two projects, carried out independently of each other between 1998 and 2002, yielded a wealth of information about the occupation history, the landscape and land use between 2000 B.C. and A.D. 1500. In both projects, archaeobotanical analysis was conducted by the author with assistance from most of the colleagues of BIAX Consult. Although both projects were carried out at the same time, and with the same people doing the botanical research, it was not possible to combine the botanical data in one comprehensive report.

Therefore the first aim of this article is to bring together the archeobotanical results from these two projects in the microregion Breda-West. The second aim is to compare these results with those from Oss and 's-Hertogenbosch, in the northeastern part of the MSD region. 


\section{The landscape of Breda-West}

The archaeological investigations at Breda-West were concentrated in three areas (A, B and C), which all lie to the west of the river Mark (Fig. 2).

Area A was studied the most intensively. This area is marked by four fairly small cover-sand ridges, which are separated from each other by stream valleys. These ridges, including the slopes, consist of relatively silt-rich Old Cover-Sands (Oud Dekzand) loess and cover-sands that were deposited during the Late Pleistocene on an impermeable layer of loam (known as 'Brabant silt'). The layer of Old Cover-Sands on the ridges is several metres thick, providing fairly well-drained and quite fertile soil. Here and there on the cover-sand ridges and slopes are depressions. At these places water runoff was hampered and, as a result, organic material was able to accumulate. Organic material also accumulated in the stream valleys. In Area A, large parts of the cover-sand ridges, the depressions and the stream valleys were almost fully excavated.

Area B lies to the southwest of Area A along the upstream part of the brook Bagvenseloop. It consists of a complex of low-lying cover-sand ridges with Old CoverSands forming the topsoil. The lower parts of this Old Cover-Sand landscape would originally have been rather wet.

Area $\mathrm{C}$ lies to the south of Areas A and B, at the edge of the valley of the brook known as 'Aa of Weerijs'. This stream joins the river Mark to the northeast (Fig. 2). This

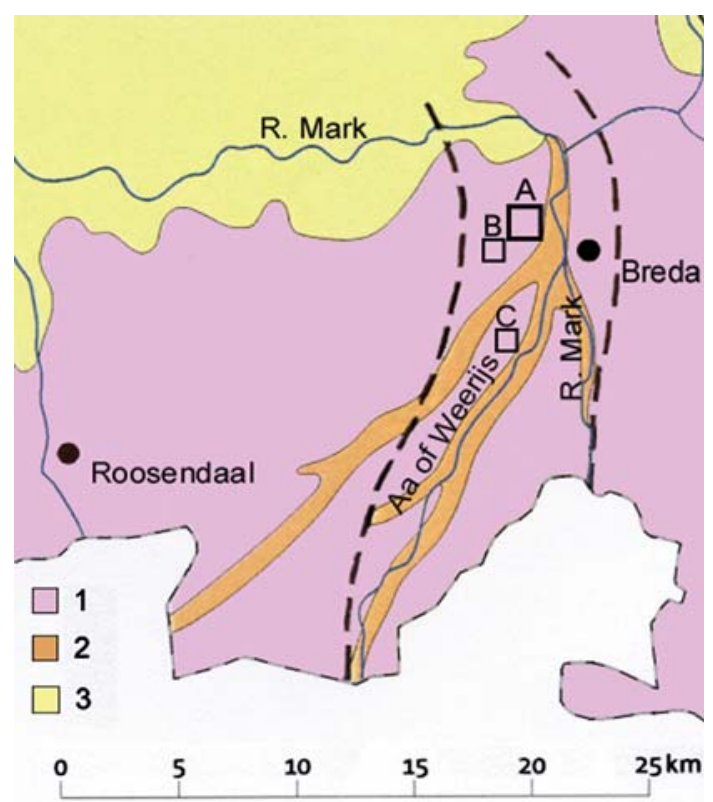

Fig. 2 Geographical situation of the micro-region Breda-West with the research areas $(A, B$ and $C$ ), the cover-sand deposits (1), river deposits (2) and the Holocene deposits (3). The dotted lines indicate the valley of the river Mark area has a deposit of cover-sands (Jong Dekzand), poor in loam. Because of its low loam content, the soil is welldrained but not very fertile. The higher-lying cover-sand and the slopes of the stream valley were probably not prone to flooding in the past.

This cover-sand topography, which by Dutch standards had quite a varied relief, remained unchanged from the late Pleistocene until the late Middle Ages. After A.D. 1500 the landscape became more level, partly because of the adoption of sod manuring (Plaggen) in agriculture.

\section{Methods}

The history of the landscape and the use of the land being important research themes, pollen analysis as well as analysis of botanical macrofossils including wood were carried out. Zoological analysis can also be very helpful where themes relating to agriculture are concerned, but in the acid sandy soil bones had been preserved poorly or not at all. Nonetheless some research into insects and mites was carried out in Area A. However, this article will concentrate on the pollen data and the botanical macrofossils.

\section{Pollen analysis}

Five pollen diagrams were made: three for Area A, one for Area B and one for Area C. These diagrams contain information about vegetation development from the Boreal (Mesolithic) into the early Middle Ages. Not all diagrams cover all periods. In the diagrams covering the same periods, the results are at any rate very similar. In this article the vegetation history is summarized on the basis of the most comprehensive diagram, that of Area C (Fig. 3). This diagram has been complemented with one spectrum covering the Boreal from one of the diagrams relating to Area A.

The pollen analysis of Area $\mathrm{C}$ was performed on organic sediments from a rest gully of the Aa of Weerijs, which were sampled by coring just south of an excavation in Area C. The lithostratigraphy, in centimeter above sea level (Dutch O.D.), is as follows:

$310-290 \mathrm{~cm}$ : organic material, peaty sand 290-282 cm: sand, not collected

$282-252 \mathrm{~cm}$ : organic material, peaty sand

252-222 cm: sand, not collected

$222-151 \mathrm{~cm}$ : organic material, peaty sand.

The Boreal sample from Area A comes from the bottom of the valley of the brook Vinkenburgloop. The sediment consisted of organic, peaty sand, covered by peat. 

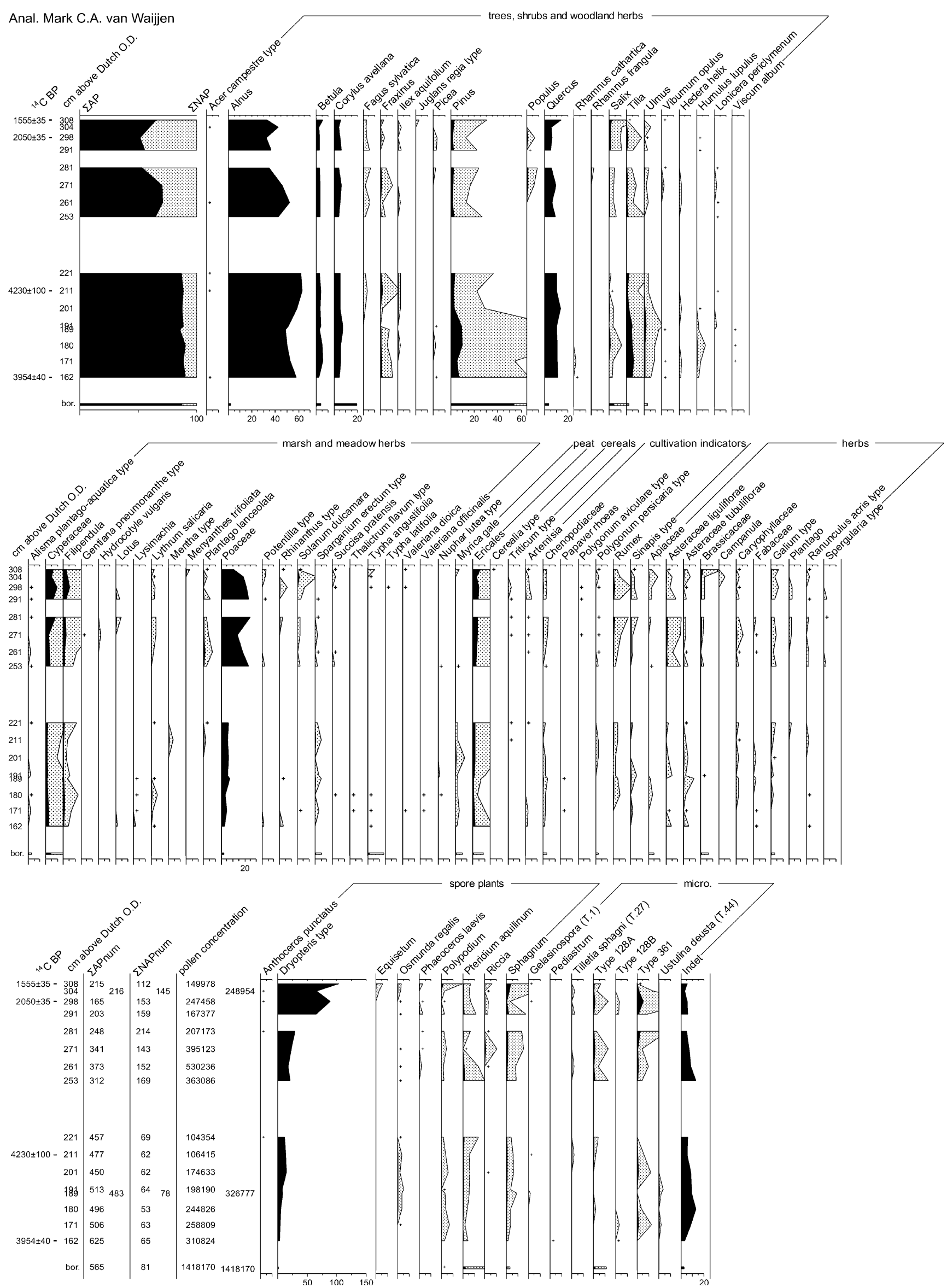

型 Springer 
4 Fig. 3 Percentage diagram of pollen and other microfossils in Area $C$; analyses by Mark C. A. van Waijjen. The lowest sample (bor. $=$ Boreal period) relates to the Mesolithic period in Area A. In the curves of the individual taxa, black indicates the actual percentage, while grey shading shows the percentage multiplied by five. A "plus" means that the taxon occurred in small numbers only

A total of 16 pollen samples were taken from the core. The vertical distance between the samples ranged between 2 and $10 \mathrm{~cm}$. Although the international standard in palynology is to sample every $\mathrm{cm}$, it is unfortunately impossible to do so in the context of Dutch commercial research.

Under laboratory conditions, subsamples of 1 to $2 \mathrm{~cm}^{3}$ were taken. The subsamples were treated according to the guidelines of Erdtman (1960) and Fægri and Iversen (1989). This method was modified by the addition of two tablets containing a known amount of exotic Lycopodium spores to allow the calculation of pollen concentrations. In the sample slides all microfossils were counted until at least 600 pollen grains had been recorded. We chose a total pollen sum enabling us to compare the results of the different pollen samples taken in Breda-West. The pollen samples were analysed by $M$. van Waijjen, using a microscope with in general a $400 \times$ magnification. The Cerealia pollen were identified using phase contrast and a magnification of $1,000 \times$. Besides pollen and spores, also other palynomorphs were counted, such as algae and soil fungi. For the identification of pollen and spores, the usual reference works were consulted (keys in Fægri and Iversen 1989; Moore et al. 1991; Punt et al 1976-2003), as well as the reference collection of BIAX Consult.

Besides the pollen subsamples four bulk samples were also taken from the core and sent to the Groningen Centre for Isotope Research to be radiocarbon dated. One of the samples was taken from the lowest, undisturbed level of the core, one from the top of the collected material, and two samples from levels containing cereal pollen. The levels and results are given in Table 1 . The ${ }^{14} \mathrm{C}$ dating of the lowest level indicated an age of 3,945 \pm 40 years B.P. (GrA-21275). At this level and the five levels above it, no pollen of Fagus occurs (Fig. 3). This is in contrast with pollen of Tilia and Viscum, which are found quite

Table 1 Breda-West, Area C. Radiocarbon datings of the pollen core from Area C; calibrated with the program Oxcal 3.10 (Bronk Ramsey (2005)

\begin{tabular}{llll}
\hline $\begin{array}{l}\text { Location } \\
\text { (cm above } \\
\text { Dutch O.D. })\end{array}$ & Lab. code & ${ }^{14}$ C age B.P. & $1 \sigma$ Age range \\
\hline 308 & GrA-21278 & $1,555 \pm 35$ & A.D. $430-540$ \\
298 & GrA-21258 & $2,050 \pm 35$ & 110 B.C. -A.D. 10 \\
211 & GrA-21277 & $4,230 \pm 100$ & $2920-2620$ в.C. \\
162 & GrA-21275 & $3,945 \pm 40$ & $2560-2340$ в.C.
\end{tabular}

Bronk Ramsey (2005) regularly. In the Netherlands this combination of pollen absence and presence is normally found in the Atlantic period (up to 3000 в.с.). Therefore it is assumed that the dating of the lowest level is too late, possibly because of contamination with tree rootlets from higher levels.

\section{Botanical macroremains}

The botanical macrofossils were recovered from archaeological features dating from the Bronze Age (2000 в.C.) up to the end of the Middle Ages (A.D. 1500) or, in some cases, the 17th century. This latter period will not be discussed in the present article.

Previous research of rural settlements in the Netherlands has shown that on average only $10-30 \%$ of the features contain botanical macroremains. Features situated above the water table especially tend to show a low density of charred botanical remains (Kooistra 2006a, 2007). But in wet conditions the density of waterlogged macroremains will normally be high. Since most of the features were above the water table, we expected most of the 51 samples to have a low density of charred seeds and fruits. For this reason we decided to take many samples from many different features: postholes of houses and granaries, pits and wells. In the first year of fieldwork we checked the density of macroremains in light-coloured features; these features proved very poor in charred material. In the following excavation years we therefore concentrated on sampling dark-coloured features and wells.

During fieldwork it is not only a feature's richness in botanical macroremains which is difficult to predict, but also the age of the features cannot always be ascertained. We chose to collect many samples $(1,508)$ from 860 different features. These were assessed in terms of quality of preservation, quantity and general composition of the botanical material contained in them (Kooistra 1996; Brinkkemper et al. 1998). On the basis of this assessment, combined with the archaeological data, 121 samples from 84 features were eventually selected for analysis. For this article only samples from well-dated features are used, which means that just 75 features are taken into account. Table 2 presents the results relating to cereals and other useful plants. Table 3 summarizes the wild plants of arable fields and of heath and marshland (after Tamis et al. 2004). In both tables the numbers reflect the number of features the taxa are found in. The samples were analysed by L. van Beurden, O. Brinkkemper, H. van Haaster, K. Hänninen, L. Kubiak-Martens and L.I. Kooistra, employing microscopes with magnifications up to 50 times and up to 400 times, and using a modern reference collection (BIAX Consult) and the relevant identification literature. 
Table 2 Breda-West; feature frequency of arable crops, oilseeds, culinary herbs and vegetables, cultivated fruits and (gathered) wild fruits per period
$B A$ bronze age, $I A$ iron age, $R P$ Roman period,

EMA early middle ages, LMA late middle ages

\begin{tabular}{|c|c|c|c|c|c|c|}
\hline $\begin{array}{l}\text { Period } \\
\text { N features } \\
\text { Area }\end{array}$ & $\begin{array}{l}\mathbf{B A} \\
\mathbf{3} \\
\mathbf{A}+\mathbf{B}\end{array}$ & $\begin{array}{l}\mathbf{I A} \\
28 \\
\mathbf{A}+\mathbf{B}+\mathbf{C}\end{array}$ & $\begin{array}{l}\text { RP } \\
10 \\
A+B\end{array}$ & $\begin{array}{l}\text { EMA } \\
16 \\
\text { A }\end{array}$ & $\begin{array}{l}\text { LMA } \\
17 \\
\mathbf{A}+\mathbf{B}+\mathbf{C}\end{array}$ & $\begin{array}{l}16 \text { th century } \\
1 \\
\text { B }\end{array}$ \\
\hline \multicolumn{7}{|l|}{ Cereals and the like } \\
\hline Avena sativa flower bases & . & . & . & 1 & 1 & . \\
\hline Fagopyrum esculentum & . & . & . & . & . & 1 \\
\hline Hordeum vulgare ssp. vulgare & 3 & 16 & 5 & 14 & 9 & . \\
\hline Hordeum sp. rachis internodes & . & 7 & 4 & 6 & 9 & . \\
\hline Panicum miliaceum & 1 & 7 & 1 & $1 \mathrm{cf}$. & . & . \\
\hline Panicum miliaceum chaff & . & 7 & 5 & . & 1 & . \\
\hline Secale cereale & . & . & 1 & 14 & 5 & . \\
\hline Secale cereale rachis internodes & . & . & . & 7 & 3 & . \\
\hline Setaria italica & . & 2 & . & . & . & . \\
\hline Triticum aestivum & . & . & . & 2 & 1 & . \\
\hline Triticum dicoccon & 2 & 5 & 2 & . & $2 \mathrm{cf}$. & . \\
\hline Triticum dicoccon gl.b. and sp.f. & 2 & 16 & 5 & . & . & . \\
\hline Triticum spelta gl.b. & . & $7+1 \mathrm{cf}$ & 1 & . & . & . \\
\hline \multicolumn{7}{|l|}{ Possible cereals } \\
\hline Avena sp. & . & 5 & 3 & 8 & 6 & . \\
\hline Avena sp. awn fragments & . & 8 & 3 & 4 & 3 & . \\
\hline \multicolumn{7}{|l|}{ Legumes } \\
\hline Pisum sativum & . & 1 & 1 & 2 & 1 & . \\
\hline Vicia faba var. minor & . & 2 & $1+1 \mathrm{cf}$ & 2 & 2 & . \\
\hline \multicolumn{7}{|l|}{ Oleiferous seeds } \\
\hline Brassica rapa & . & $1 \mathrm{cf}$. & 1 & . & . & . \\
\hline Camelina sativa & . & 4 & . & 2 & 2 & . \\
\hline Camelina sativa siliqua fragments & . & . & . & . & 1 & . \\
\hline Linum usitatissimum & . & 8 & 2 & 2 & 4 & . \\
\hline Linum usitatissimum capsule fragments & . & 3 & 2 & 3 & 2 & . \\
\hline Papaver somniferum & . & . & 1 & . & . & . \\
\hline Papaver somniferum cf. ssp. setigerum & . & 1 & . & . & . & . \\
\hline \multicolumn{7}{|l|}{ Cultivated and collected fruit } \\
\hline Crataegus cf. monogyna & . & . & 1 & . & . & . \\
\hline Malus sylvestris & . & . & . & 1 & . & . \\
\hline Prunus domestica ssp. insititia & . & . & 1 & 1 & . & . \\
\hline Prunus spinosa & . & . & . & 2 & 1 & . \\
\hline Rubus caesius & . & . & . & 1 & . & . \\
\hline Rubus idaeus & . & 6 & 3 & 6 & 3 & . \\
\hline Rubus fruticosus & . & 6 & 2 & 12 & 4 & 1 \\
\hline Sambucus nigra & . & 4 & 2 & 1 & 1 & . \\
\hline \multicolumn{7}{|l|}{ Nuts } \\
\hline Corylus avellana & . & 3 & 1 & 11 & 1 & . \\
\hline Quercus sp. acorn fragments & . & 3 & . & 1 & 2 & . \\
\hline \multicolumn{7}{|l|}{ Vegetables and kitchen herbs } \\
\hline Apium graveolens & . & . & . & 1 & . & . \\
\hline Beta vulgaris & . & . & . & . & 1 & 1 \\
\hline Valerianella locusta & . & . & . & 2 & . & . \\
\hline \multicolumn{7}{|l|}{ Possible medicinal plants } \\
\hline Ballota nigra & $\cdot$ & $1 \mathrm{cf}$. & 1 & . & . & . \\
\hline Hyoscyamus niger & . & 1 & . & . & 1 & . \\
\hline
\end{tabular}

\section{Results}

The Mesolithic: the pristine landscape

Evidence from the Mesolithic, 9,000-8,000 years ago, was found only in two places in Area A. As the results were very similar, only one of the samples will be presented here.
At this time level, the share of arboreal pollen is about $85 \%$. The dominance of Pinus is notable, while pollen of C. avellana, Betula, Quercus and Salix is represented by values of about 5\% each. Tilia is almost absent and Alnus makes up just $1 \%$. Although the proportion of tree pollen is high, the vegetation did not constitute a dark dense woodland, given the fact that trees such as Pinus, 
Table 3 Breda-West; feature frequency of arable weed assemblages and plants of heathlands and marshlands by period
See Table 2; $\mathrm{B}=$ found in Area $\mathrm{B} ; *$ = plants may occur in several ecological groups

\begin{tabular}{lllllll}
\hline Period & BA & IA & RP & EMA & LMA & 16th century \\
N features & 3 & 28 & 10 & 16 & 17 & 1 \\
Area & A+B & A + B + C & A + B & A & A+B + C & B \\
\hline
\end{tabular}

Moderately nutrient-rich acid sandy soils

Aethusa cynapium

Agrostemma githago

Anagallis arvensis

Avena fatua

Cuscuta epilinum

Euphorbia helioscopia

Fallopia convolvulus

Lamium purpureum

Persicaria maculosa

Solanum nigrum s.1.

Sonchus arvensis

Sonchus asper

Stellaria media

Thlaspi arvense

Urtica urens

Vicia hirsuta + tetrasperma

Lime-rich soils

Galium spurium

Sherardia arvensis

Moderately nutrient-poor acid sandy soils

Anthemis arvensis

Apera spica-venti

Aphanes microcarpa

Arnoseris minima

Centaurea cyanus

Chrysanthemum segetum

Echinochloa crus-galli

Erodium cicutarium

Galeopsis ladanum/segetum

Galeopsis speciosa/tetrahit

Hypochaeris glabra/radicata

Papaver argemone

Raphanus raphanistrum

Rumex acetosella*

Scleranthus annuus

Spergula arvensis

Stachys arvensis

\begin{tabular}{cc}
\multicolumn{3}{l}{ cid sandy soils } \\
. & $\cdot$ \\
. &. \\
. & 2 \\
. & 1 \\
. & $\cdot$ \\
. &. \\
1 & 9 \\
. &. \\
. & 9 \\
. & 7 \\
. & $\cdot$ \\
. &. \\
. & 8 \\
. & $\cdot$ \\
. &. \\
1 & 2
\end{tabular}

$\begin{array}{llll}. & 1 & . & . \\ . & 1 & 2 & . \\ . & 4 & 5 & . \\ 2 & . & . & . \\ . & 1 & 1 & . \\ 3 & 9 & 4 & . \\ 2 & 1 & . & . \\ 6 & 3 & 4 & 1 \\ 3 & 8 & 5 & 1 \\ . & 1 & . & . \\ . & . & 2 & . \\ 3 & 11 & 7 & 1 \\ . & 2 & . & . \\ 2 & 1 & 1 & . \\ 1 & 8 & 10 & .\end{array}$

\section{Heathlands and marshlands}

Calluna vulgaris

Carex curta

Carex oederi

Erica tetralix

Juncus squarrosus

Molinia caerulea

Potentilla erecta

Ranunculus flammula

Rumex acetosella*

Viola palustris

$\begin{array}{llllll}. & 2 \mathrm{~B} & 1 \mathrm{~B} & 4 & 4 & 1 \\ . & . & 1 \mathrm{~B} & . & 1 & 1 \\ . \mathrm{B} & 1 \mathrm{~B} & 1 \mathrm{~B} & 1 & . & . \\ . & \text {. } & 2 \mathrm{~B} & 3 & 5 & 1 \\ . & 1+2 \mathrm{~B} & 1 \mathrm{~B} & 1 & . & . \\ . & 4+2 \mathrm{~B} & 4 & 6 & 4 & 1 \\ . & 5+4 \mathrm{~B} & 4+1 \mathrm{~B} & 5 & 3 & 1 \\ . & 13 & 4 & 12 & 14 & 1 \\ . & 1 \mathrm{~B} & . & . & . & .\end{array}$

C. avellana and Betula are light-demanding. The presence of Pteridium aquilinum also points to fairly open woodland.

This open Pinus wood with much light is thought to have occurred on the cover-sand ridges and slopes. The stream valleys were quite densely wooded with Salix. This is assumed because Salix pollen tends to be under-represented (Andersen 1970, 1973), and the presence of 5\% pollen of this type indicates that willow formed a substantial part of the vegetation. Virtually no herb pollen was encountered here. Plants growing in the water and along the waterside included Alisma plantago-aquatica, Sparganium erectum 
type and Typha angustifolia. Although no truly aquatic plants were identified, the presence of T. angustifolia indicates stagnant or slowly moving water up to $1.5 \mathrm{~m}$ deep (Weeda et al. 1994, pp 243-244). The archaeological and botanical research produced no evidence of human presence during the Mesolithic.

The Neolithic: settlements in woodland

Pollen diagrams from all three areas provided information about the Neolithic. The proportion of trees and shrubs versus herbs (the AP/NAP ratio) lies around 90:10 for this period. Most of the tree pollen derives from deciduous trees. Besides tree pollen proper, pollen of shrubs or small trees was found, such as C. avellana, Rhamnus cathartica, Ilex aquifolium and Viburnum opulus. Viscum album appears regularly in the pollen diagrams. Viscum album is a partial parasite that grows in treetops, and is nowadays rarely found in the Netherlands except in the south of the province of Limburg. But it is common in pollen samples from the Atlantic period.

The picture arising from the pollen diagrams is that of a fairly closed woodland, on the higher cover-sands as well as in the river valleys. The valleys also contained elements of a low-nutrient, slightly acid bog vegetation, including Osmunda regalis, Sphagnum mosses and Myrica gale. The results from Area $\mathrm{C}$ fit with the results from Area A and indicate mixed, broadleaved woodland on medium nutrient-rich soil (Brandenburgh and Kooistra 2004; Gouw and Kooistra 2006). In Area B (on the upper stretch of the Bagvenseloop) a combination of pollen was recorded (Gouw and Kooistra 2006) that brings to mind modern-day mixed oak woods on nutrient-poor, moist to wet soils (Hommel et al. 1999, pp 255-257).

At 211 and $221 \mathrm{~cm}$ above Dutch O.D., pollen of cereals (Cerealia type) was recovered. Particularly because of this cereal pollen, the level at $211 \mathrm{~cm}$ above Dutch O.D. was radiocarbon dated. Its age was established at between 2920 and 2620 в.c. (see Table 1). The presence of cereals in the late Neolithic indicates that human activity occurred near the stream valley. Other possible indicators of human presence are the pollen of Artemisia and Plantago lanceolata, which were also found. The latter is interpreted by Behre as an indicator of wet or moist grassland, and the former as an indicator of disturbed soil, fallow fields or woodland pasture (Behre 1981, p 233). In spite of human presence, the natural composition of the vegetation was hardly affected. People probably lived in woodland clearings, presumably practising both arable farming and animal husbandry. Archaeological evidence of the Neolithic in the three areas is limited to some stray finds.
The Bronze Age and Iron Age: living among scattered tree stands

The pollen picture undergoes a distinct change as we come to the Bronze and Iron Ages. The proportion of trees and shrubs versus herbs decreases from $90 / 10$ to approximately $65 / 35$ at $253 \mathrm{~cm}$ above Dutch O.D. (Fig. 3). The drop in the percentage of tree pollen is largely due to a decline in alder. As regards the herbs, there was an increase in the curves of Poaceae, Cyperaceae, Filipendula, Galium type, Lotus, Lythrum salicaria, Rhinanthus type and Potentilla type. This suggests that the alder carr woodland, in particular in the stream valleys, was partly replaced by moist to wet grassland. In the period represented by the levels between 261 and $271 \mathrm{~cm}$, the woodland seems to have recovered somewhat. This is apparent primarily from the curves of Alnus and Quercus. The curves of typical woodland plants like Hedera helix and Lonicera periclymenum also show minor peaks at these levels, with the values of grasses declining concurrently.

From $271 \mathrm{~cm}$ above Dutch O.D. upward, the proportion of tree pollen falls again. From here on, the percentage of grass pollen increases and we find grains of cereal pollen (including Triticum type). These findings, in combination with the presence of plants such as Polygonum aviculare, Rumex and one or more species of the Chenopodiaceae, indicate human activity in the vicinity. The alternation of open landscape and moderately dense woodland, which is clearly evident from the diagram for Area C, suggests the following attractive hypothesis. The alternation in the vegetation structure may be explained by the 'unsettled settlement' occupation model of Schinkel (1998). While the territory of Area $\mathrm{C}$ was in continuous use, one generation would live and farm closer to or farther from our sampling point in the stream valley than the previous or the next generation.

For this period too, the vegetation picture of Area B differs a little from that of Areas A and C (Brandenburgh and Kooistra 2004; Gouw and Kooistra 2006). The strong decline in the percentage of tree pollen does not distinguish Area B from the two other areas, but in Area B heathland seems to have developed (Gouw and Kooistra 2006). This may have been a result of Neolithic farming on the locally rather nutrient-poor sandy soil. Arable farming in particular would have exhausted the soil, poor as it already was, after which it would sustain only heathland vegetation (Casparie and Groenman-Van Waateringe 1980).

Samples with botanical macroremains dating from the Bronze Age are scarce in all three areas studied. Only three Bronze Age features contained some botanical macroremains. In these samples $H$. vulgare subsp. vulgare (hulled six-row barley), T. dicoccon (emmer wheat) and $P$. miliaceum (millet) were found, and it is likely that 
these cereals formed part of people's diet (Table 2). The farmhouse structures are suggestive of arable farming and animal husbandry, but this could not be corroborated by botanical evidence, because hardly any remains of wild plants were found.

At least 28 Iron Age features were investigated for botanical macroremains. During the Iron Age the same crops were grown as in the Bronze Age. Besides these, T. spelta (spelt wheat) was regularly found and single specimens of Setaria italica (foxtail bristle-grass) and Papaver somniferum cf. ssp. setigerum (poppy) turned up. It was interesting to discover three burnt granaries from the early Iron Age at a site in Area A, in which large quantities of acorns had been stored. Acorns are highly nutritious and quite suitable for human consumption, provided the toxic substances they contain are first leached out (Mason 1995, 2000; Jørgensen 1977). At 10 or so Bronze and Iron Age sites elsewhere in the Netherlands, large amounts of charred acorns have been found, which were probably intended for human consumption (Van Beurden 2000; Buurman 1986, 1990, 1998; Van Zeist 1968; Van Zeist and Palfenier-Vegter 1996).

On the basis of the arable weeds found, it may be assumed that the cereals were grown locally, because most of the weeds belong on moderately nutrient-poor, limedeficient, sandy soil (see Table 3). Not only botanical sources provide evidence of agrarian settlements. The location and the structure of the buildings, the presence of granaries, the find of a ploughshare from the middle Iron Age (500-250 в.с.) at a site in Area B, and the lack of clear evidence of craft activity all point in the same direction (Kooistra 1996, 14-22).

The agrarian economy comprised agriculture as well as animal husbandry. The brook valleys probably provided some of the pasture for the livestock. The arable fields were mainly located on the cover-sand ridges and slopes.

The Roman period: nothing new under the sun?

At the level of $298 \mathrm{~cm}$ below Dutch O.D., around the transition from the late Iron Age to the early Roman period (110 B.C.-A.D. 10, see Table 1), the share of tree pollen drops to values around 52\% (Fig. 3). At this level it seems that people began to use the landscape in a far more intensive way. This is confirmed by a small peak in the percentage of cereals and an increase of various arable weeds and ruderals (plants growing on fallow land). Human activities were not restricted to the higher coversand areas; changes can also be observed in the vegetation in the stream valley, given the declining curve of alder and the rising curves of, among other plants, Cyperaceae and Dryopteris type. A comparable development, accompanied by the presence of grasses and expansion of Plantago lanceolata, was observed in the valley of the river Roer
(Bunnik 1999, 116-117). His conclusion, which also applies to the valley of the Aa of Weerijs, is that part of the alder carr in the river valley was cut down and turned into damp pasture. The gradual expansion of Sphagnum and Ericales, including Calluna vulgaris, can be regarded in this light, but also indicates local acidification of the soil.

In terms of botanical macroremains, the picture arising from the data of the Roman period differs little from that of the Iron Age, but only ten features contained significant numbers of botanical remains. The assortment of cereals includes $H$. vulgare ssp. vulgare (hulled six-row barley), T. dicoccon (emmer wheat), P. miliaceum (common millet) and a single glume base of $T$. spelta (spelt wheat). It almost seems that the Roman period completely passed the region's inhabitants by. The charcoal spectrum, for example, does not indicate any import of timber (Kooistra 2006b). So there was nothing new under the sun in Roman times; or was there? The presence of pollen of J. regia (walnut), at $308 \mathrm{~cm}$ above Dutch O.D. in a level that was radiocarbon dated A.D. 430540 (Table 1) indicates that at least some change took place (Fig. 3). Walnut was introduced into the Netherlands in Roman times. Nutshell fragments from this period have been found at many sites. In pollen diagrams, however, walnut usually appears at a slightly later date, beginning with the late Roman period or the early Middle Ages (for example, Bakels 1996; Bunnik 1999; Munaut 1967; Teunissen 1990). An explanation for this time lag may be that walnut trees were originally planted in domestic gardens, from which they escaped into the wild. Newly introduced exotic trees usually do not show up in pollen diagrams until they spread, naturally or through human intervention.

The early and high Middle Ages: the beginning of continuous cultivation of $S$. cereale (rye)

In the top pollen spectrum, at $308 \mathrm{~cm}$ above Dutch O.D. (Fig. 3), which relates to the early Middle Ages, Sphagnum, Myrica gale and Ericales show an increase as compared to the older spectra. This may merely reflect patches of these taxa near the sampling points in the stream valley, but it should be noted that leaves of Erica tetralix and Calluna vulgaris also appear regularly in the samples of macrofossils from Areas A and C, from the early Middle Ages onward. It seems, therefore, that heath vegetation spread into the wider environment.

Heathlands were not the only novelty in the medieval landscape. There are indications of a brackish coastal environment, the earliest pointers coming from the mite fauna study conducted by Schelvis (2003). A sample from Area A, dated A.D. 900-1250, contained a significant number of mites (species as well as individuals) that occur especially in salt-marsh vegetation. Furthermore, a postmedieval sample (dated A.D. 1500-1550) in Area B 
Fig. 4 Seeds of a Oenanthe lachenalii; b Triglochin maritima; c Arnoseris minima; d Aphanes microcarpa. Photos by M. van Waijjen (BIAX Consult), scale bar equals $0.5 \mathrm{~mm}$
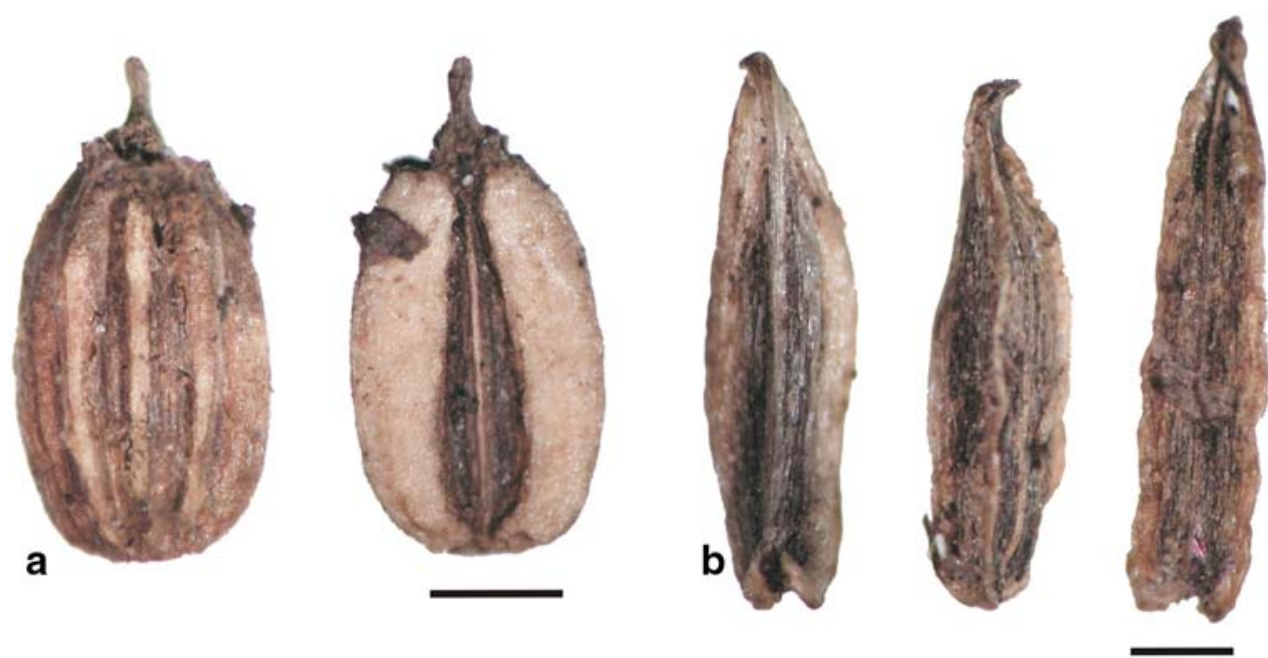
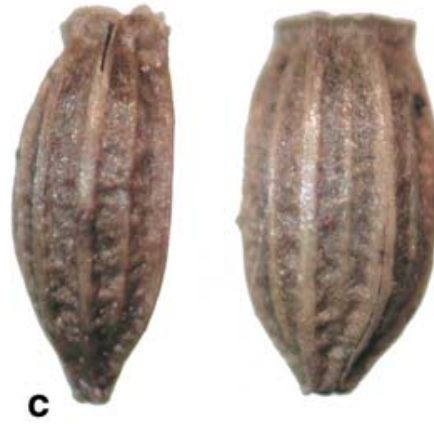
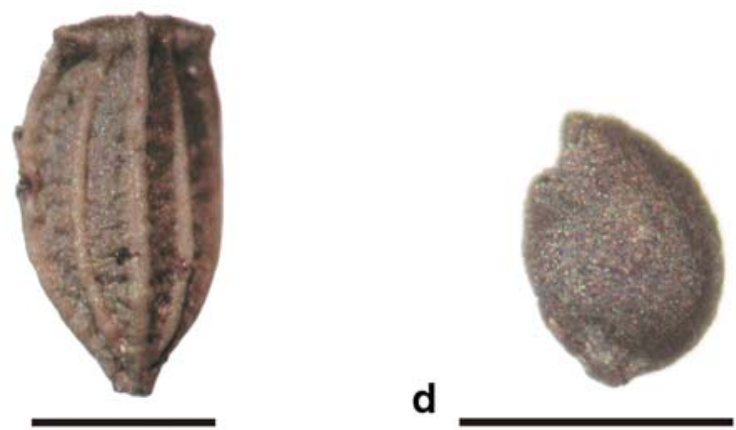

d contained seeds of plants that essentially belong to moist brackish grassland (Fig. 4), namely Oenanthe lachenalii and Triglochin maritima. The presence of these species is living proof of a change in character of the river Mark and of greater marine influence, corroborating the many historical sources that mention these changes.

Owing to the many floods that occurred in the 14th and 15 th centuries, the landscape and its use changed. This applies in particular to the area northwest of Breda. In the early 16th century, the Mark, a narrow river today, was $350 \mathrm{~m}$ wide and tidal in its lower reaches. The occurrence of inundations does not necessarily mean that salt or brackish water reached Breda and the surrounding land, but we know that this was indeed the case from various sources, including historical sources that mention peat burning for salt extraction in the former peatlands west of Breda (Leenders 1989, pp 100-101).

From the early Middle Ages S. cereale (rye) and $H$. vulgare ssp. vulgare (hulled six-row barley) were the main crops in the Breda region. The first $F$. esculentum (buckwheat) was found in a 16th century well in Area B. During the Middle Ages the number of arable weeds of the Sclerantho annui-Arnoseridetum increased. This weed association occurs in fields where rye is cultivated continuously without fallow periods. Dominant weeds in such fields are Arnoseris minima and Aphanes microcarpa (see
Fig. 4). This association can only develop in fields where a winter cereal is grown year after year. Fallow periods and crop rotations with spring-sown cereals are fatal for this specific weed association. There was only one type of cereal that could cope with such intensive cultivation on poor soil, and this was rye. But even the rye yields would diminish without intensive manuring. In the late Middle Ages the fields were probably manured exclusively with organic substances (both animal and vegetable matter), given the facts that the excavated farmsteads of this period do not have deep-litter byres, and the plaggen soils are of more recent date. But the fact that by A.D. 1500-1550 the composition of the arable weeds in Area B was fully adapted to continuous rye cultivation implies that sod manuring was indeed practised. This was later than in other parts of the Netherlands or northwestern Germany, where this weed association and sod manuring occurred together even in the early Middle Ages (Behre 1993).

Differences and similarities between the northeast and the northwest of the MSD region

There are many similarities between the two investigated micro-regions. In both of them the first loss of woodland started in the Neolithic with woodland clearings. From the Bronze Age onwards, the area of woodland decreased in 
both micro-regions. In the northeastern part, the woodland was locally replaced by heathland even in the Bronze Age (Bakels 2002; De Kort 2002; Van Beurden 2002a). During the Bronze Age in the Breda micro-region, heathland only occurred in Area B. This area is located on moderately nutrient-poor soil, which explains the early development of heathland there. But there as well as in Areas A and C patches of deciduous woodland continued to be features of the landscape well into the early Middle Ages.

The picture sketched by Schinkel of prehistoric occupation in the central and eastern parts of the province of Noord-Brabant appears also to hold for the Breda region (Schinkel 1998; Koot and Berkvens 2004; Kranendonk et al. 2006). The same crops were grown and the same foodstuffs eaten.

From the late Iron Age onwards, farmsteads in the two regions appear to have occupied the same sites for several generations, whereas previously they had been shifted around. The more permanent character of the settlements allowed the surrounding land to be used more intensively. This probably led to soil exhaustion and hence the disappearance of $T$. spelta (spelt wheat) during the Roman period (see Table 2). This trend is observed in both microregions and runs counter to developments in the loess soil region of Zuid-Limburg and the German Rhineland, where during the Roman period spelt wheat was the most important crop (Kooistra 1996). So far, there is little archaeological evidence to mark the Roman period in the Breda region. Moreover, due to the poor preservation of the remains, botanical evidence relating to this region during the Roman period is also scanty. Maybe this is why none of the Mediterranean kitchen herbs and exotic fruits were found, although these products do occur in the northeast of the MSD region and indeed at farming settlements throughout the Roman province of Germania inferior.

Presumably as a result of further intensification in arable farming, the early Middle Ages show a change in crop range. From this time on, S. cereale (rye) became the primary crop to the west of Breda, as was the case elsewhere on the sandy soils of the MSD region (Van Beurden 2002b; Van Haaster 2003). An increase in arable weeds may point to an intensification of arable farming in the early Middle Ages (Table 3). However, this increase may also be due to a changed sowing regime of the various cereals. In prehistoric times the cereals were usually sown in spring, whereas in the early Middle Ages rye was sown in autumn and harvested the following summer. Intensification of arable farming could only be achieved if the fields were better manured. Van Haaster (2003) concluded that in the vicinity of 's-Hertogenbosch, permanent rye cultivation started in the late 13th century. Present results suggest that in the Breda region this type of cultivation did not start until the beginning of the postmedieval period.

\section{Conclusions}

In terms of vegetation history and development of agriculture, the micro-region of Breda-West and that of 's-Hertogenbosch and Oss-Ussen are to a large extent comparable.

Pollen analyses have shown that during the Neolithic the landscape in both micro-regions was covered with woodland, and it appears that these regions were gradually cleared through human activity after the beginning of the Bronze Age. In contrast to the micro-region around 's-Hertogenbosch and Oss-Ussen, the first large heathlands in the Breda region did not appear until the early Middle Ages. Only on the poor soils of Area B did heathland develop in the Bronze Age.

In both micro-regions the same cereals were produced in the same periods. However, around Breda the lack of any Mediterranean kitchen herbs and exotic fruits during the Roman period is remarkable. This result may be due to the small number of samples available from this period. Future investigations will hopefully shed light on this question. Another point on which the Breda micro-region differs from that of 's-Hertogenbosch/Oss-Ussen is the later adoption of permanent rye cultivation: in the 16th century rather than the 13th century.

Acknowledgments K-E Behre, Caroline Vermeeren, Henk van Haaster and Otto Brinkkemper have commented on earlier drafts of this paper, which helped improve the final result. Thanks are due also to the colleagues of BIAX Consult for their help in analysing samples. The text was translated by Xandra Bardet. Last but not least I would like to thank Corrie Bakels, who interested me 25 years ago in this wonderful discipline which she called "palynology and palaeoethnobotany".

\section{References}

Andersen ST (1970) The relative pollen productivity and pollen representation of north European trees, and correction factors for tree pollen spectra. Danmarks Geologiske Undersøgelse Række II 96:1-99

Andersen ST (1973) The differential pollen productivity of trees. In: Birks HJB, West RG (eds) Quaternary plant ecology. Blackwell, Oxford, pp 109-115

Bakels CC (1980) De bewoningssporen van de Maaskant I: Plantenresten uit de Bronstijd en Romeinse Tijd gevonden te Oss-IJsselstraat. Prov. Noordbrabant [Settlement traces along the Meuse I: plant remains from the Bronze Age and Roman period found at Oss-IJsselstraat. Prov. Noordbrabant]. Analecta Praehistorica Leidensia 13:115-131

Bakels CC (1996) The pollen diagram Voerendaal-7. In: Kooistra LI (ed) Borderland farming. Possibilities and limitations of farming in the Roman period and early Middle Ages between Rhine and Meuse Van Gorcum. Assen, pp 139-146

Bakels CC (1998) Fruits and seeds from the Iron Age settlements at Oss-Ussen. Analecta Praehistorica Leidensia 30:338-348

Bakels CC (2002) Het pollendiagram Oss 45E/346 [The pollen diagram Oss 45E/346]. In: Fokkens H, Janssen R (eds) 2000 jaar bewoningsdynamiek Brons-en IJzertijdbewoning in het Maas- 
Demer-Scheldegebied. Faculteit der Archeologie, Leiden, pp 259-270

Bakels CC, Van der Ham RWJM (1980) Verkoold afval uit een Midden-Bronstijd en een Midden-IJzertijd nederzetting op de Hooidonkse Akker, gem. Son en Breugel, prov. Noord-Brabant [Carbonized waste from a Middle Bronze Age settlement on the Hooidonkse Akker, Son en Breugel, prov. Noord-Brabant]. Analecta Praehistorica Leidensia 13:81-91

Bakels CC, Wesselingh D, Van Amen I (1997) Acquiring a taste: the menu of Iron Age and Roman Period farmers at Oss-Ussen. The Netherlands. Analecta Praehistorica Leidensia 29:193-211

Behre KE (1981) The interpretation of anthropogenic indicators in pollen diagrams. Pollen et Spores 23:225-245

Behre KE (1993) Die tausendjährige Geschichte des TeesdalioArnoseridetums. Phytocoenologia 23:449-456

Brandenburgh CR, Kooistra LI (2004) Landschap en vegetatieontwikkeling [Landscape and vegetation history]. In: Koot CW, Berkvens R (eds) Erfgoedstudies Breda 1. Bredase akkers eeuwen oud. 4000 jaar bewoningsgeschiedenis op de rand van zand en klei. Rapportage Archeologische Monumentenzorg 102:37-53

Brinkkemper O, Eerden MC, Van der Graaf K, Van Heeringen RM, Kerkhoven AA, Kosian MC, Meijers HJM, Peeters JHM, Roorda IM, Sarfatij H, Schute IA (1998) Handboek van ROB-specificaties-juni 1998 [Handbook of ROB-specifications-June 1998]. Amersfoort

Bronk Ramsey C (2005) Oxcal v3.10. Research laboratory for archaeology. University of Oxford, Oxford

Bunnik FPM (1999) Vegetationsgeschichte der Lössbörden zwischen Rhein und Maas von der Bronzezeit bis in die frühe Neuzeit. Thesis, Utrecht

Buurman J (1986) Graan in IJzertijd-silo's uit Colmschate [Cereals from Iron-Age silos at Colmschate]. In: Van Heeringen RM (ed) Voordrachten gehouden te Middelburg ter gelegenheid van het afscheid van Ir. JA. Trimpe Burger als provinciaal archeoloog van Zeeland. Nederlandse Archeologische Rapporten, vol 3, pp 67-73

Buurman J (1990) Verkoolde eikeltjes uit de IJzertijd [Carbonized acorns from the Iron Age]. Nieuwsblad Monumentenzorg en Archeologie, Gemeentewerken Amersfoort 22-4:3-4

Buurman J (1998) Verkoolde plantenresten uit afvalkuilen uit de Midden-Bronstijd op de Rieler Enk te Deventer [Carbonized plant remains from Middle Bronze Age pits at the Rieler Enk, Deventer]. Interne Rapporten Archeobotanie ROB 1998/25. Amersfoort

Casparie WA, Groenman-Van Waateringe W (1980) Palynological analysis of Dutch barrows. Palaeohistoria 22:7-65

De Hingh AE (2000) Food production and food procurement in the Bronze Age and Early Iron Age (2000-500 BC). Archeological Studies Leiden University 7, Leiden

De Kort JW (2002) Schapen op de heide. Een vegetatiereconstructie van de omgeving van het vorstengraf van Oss in de Vroege IJzertijd [A reconstruction of the vegetation in the vicinity of the royal burial at Oss in the Early Iron Age]. In: Fokkens H, Jansen R (eds) 2000 jaar bewoningsdynamiek: Brons- en ijzertijdbewoning in het Maas-Demer-Scheldegebied. Faculteit der Archeologie, Leiden, pp 341-353

Erdtman G (1960) The acetolysis method. Svensk Botanisk Tidskrift 54:561-564

Fægri K, Iversen K (1989) Textbook of pollen analysis (4th edn). In: Fægri K, Kaland PE, Krzywinski K (eds) Wiley, Chichester

Gouw M, Kooistra LI (2006) Geologie, bodem en vegetatie [Geology, soil, vegetation]. In: Kranendonk P, van der Kroft P, Lanzing J, Meijlink B (eds) Witte vlekken ingevuld. Archeologie in het tracé van de HSL-Zuid. Rapportage Archeologische Monumentenzorg, vol 113, pp 113-164
Hommel PWFM, Van Dort KW, Schaminée JHJ (1999) Quercetea Robori-Petraeae. Klasse der eiken- en beukenbossen op voedselarme grond [Quercetea Robori-Petraeae. Class of oak and beech forests on nutrient-poor soils]. In: Stortelder AFH, Schaminée JHJ, Hommel PWFW (eds) De vegetatie van Nederland. Deel 5. Plantengemeenschappen van ruigten, struwelen en bossen Opulus. Uppsala/Leiden, pp 255-286

Jørgensen G (1977) Acorns as a food-source in the Later Stone Age. Acta Archaeologica 48:233-238

Kooistra LI (1996) Borderland farming. Possibilities and limitations of farming in the Roman period and early Middle Ages between the Rhine and Meuse. Van Gorcum, Assen

Kooistra LI (2006a) De zin van botanisch waarderen in het voortraject [The usefulness of botanical assessments in field evaluations]. Archeobrief 10:16-19

Kooistra LI (2006b) Resultaten van het botanisch onderzoek [Archaeobotanical evidence]. In: Kranendonk P, van der Kroft P, Lanzing J, Meijlink B (eds) (2006) Witte vlekken ingevuld. Archeologie in het tracé van de HSL-Zuid. Rapportage Archeologische Monumentenzorg, vol 113, pp 772-773

Kooistra LI (2007) Botanical assessment in archaeological field evaluations: a must or a bridge too far. Amersfoort, (NAR) Rijksdienst voor Archeologie, Cultuurlandschap en Monumenten, $\mathrm{p} 8$

Koot CW, Berkvens R (2004) Erfgoedstudies Breda 1. Bredase akkers eeuwen oud. 4000 jaar bewoningsgeschiedenis op de rand van zand en klei [ 4000 years of occupation on the cover-sands margin near Breda]. Rapportage Archeologische Monumentenzorg 102, Amersfoort

Kranendonk P, Van der Kroft P, Lanzing J, Meijlink B (2006) Witte vlekken ingevuld. Archeologisch onderzoek in het tracé van de HSL-Zuid [Archaeological investigation of the projected railway track HSL-South]. Rapportage Archeologische Monumentenzorg 113, Amersfoort

Leenders KAHW (1989) Verdwenen venen. Een onderzoek naar de ligging en exploitatie van thans verdwenen venen in het gebied tussen Antwerpen, Geertruidenberg en Willemstad 1250-1750 [Lost peatlands. Investigations into the location and exploitation of now lost peatlands in the area between Antwerp, Geertruidenberg and Willemstad AD 1250-1750]. Gemeentekrediet Historische Uitgaven, reeks in- $8^{\circ}$, no. 78

Mason SLR (1995) Acornutopia? Determining the role of acorns in past human subsistence. In: Wilkins J, Harvey D, Dobson M (eds) Food in antiquity. University of Exeter Press, Exeter, pp $12-24$

Mason SLR (2000) Fire and Mesolithic subsistence-managing oaks for acorns in northwest Europe?. Palaeogeogr Palaeoclimatol Palaeocol 164:139-150

Moore PD, Webb JA, Collinson ME (1991) Pollen analysis, 2nd edn. Blackwell, Oxford

Munaut AV (1967) Étude paléo-écologique d'un gisement tourbeux situé à Terneuzen (Pays-Bas). Berichten van de Rijksdienst voor het Oudheidkundig Bodemonderzoek 17:7-27

Punt W et al (1976-2003) The Northwest European Pollen Flora (NEPF), vol I (1976), vol II (1980), vol III (1981), vol IV (1984), vol V (1988), vol VI (1991), vol VII (1996). Elsevier, Amsterdam

Schelvis J (2003) Verslag van het onderzoek aan resten van ongewervelden afkomstig uit 5 grondmonsters genomen uit waterputten van de HSL-opgraving Westrik [Report on the investigation of remains of invertebrates from five wells in the excavation HSL-Westrik]. Rapport 87. Wirdum

Schinkel K (1998) Unsettled settlement, occupation remains from the Bronze Age and the Iron Age at Oss-Ussen. The 1976-1986 excavations. Analecta Praehistorica Leidensia 30:5-306 
Tamis WLM, Van der Meijden R, Runhaar J, Bekker RM, Ozinga WA, Odé B, Hoste I (2004) Standaardlijst van de Nederlandse flora 2003 [Standard list of the Dutch flora 2003]. Gorteria 30-4/ 5:101-195

Teunissen D (1990) Palynologisch onderzoek in het oostelijk rivierengebied; een overzicht [Palynological research in the Dutch Eastern River Area; a review]. Mededelingen van de Afdeling Biogeologie van de Discipline Biologie van de KU Nijmegen 16, Nijmegen

Van Beurden LM (2000) Archeobotanie: de macroresten [Archaeobotany: the macroremains]. In: Hiddink HA (ed) Archeologisch onderzoek in de Maasbroeksche Blokken te Boxmeer 2. De opgravingscampagne van 1998. Rapportage Archeologische Monumentenzorg, vol 76, pp 51-70

Van Beurden LM (2002a) Vegetatieontwikkeling en landgebruik vanaf het Laat-Mesolithicum tot in de Middeleeuwen in de omgeving van 's-Hertogenbosch [Vegetation history and land use from Late Mesolithic to Medieval times in the vicinity of 's-Hertogenbosch]. In: Fokkens H, Jansen R (eds) 2000 jaar bewoningsdynamiek: Brons- en ijzertijdbewoning in het Maas-
Demer-Scheldegebied. Faculteit der Archeologie, Leiden, pp 267-281

Van Beurden LM (2002b) Botanisch onderzoek in het Maas-DemerScheldegebied. De Romeinse en vroegmiddeleeuwse periode [Botanical investigations in the Meuse - Demer - Scheldt area. The Roman and early Medieval Periods]. In: Fokkens H, Jansen R (eds) 2000 jaar bewoningsdynamiek: Brons- en ijzertijdbewoning in het Maas-Demer-Scheldegebied. Faculteit der Archeologie, Leiden, pp 287-314

Van Haaster H (2003) Archeobotanica uit 's-Hertogenbosch [Archaeobotanical remains from 's-Hertogenbosch]. Thesis, Amsterdam

Van Zeist W (1968) Prehistoric and early historic foodplants in the Netherlands. Palaeohistoria 14:41-173

Van Zeist W, Palfenier-Vegter RM (1996) The archaeobotany of Peelo 3. Iron Age and Roman period. Palaeohistoria 37/38:481490

Weeda EJ, Westra R, Westra C, Westra T (1994) Nederlandse oecologische flora. Wilde planten en hun relaties 5 [Dutch ecological flora. Wild plants and their relationships 5]. Rijswijk 